\title{
Structural changes in industrial R\&D in Europe and the US: towards a new model?
}

\author{
Dominique Foray and Stéphane Lhuillery
}

\begin{abstract}
We analyse the structural changes that have characterised the organisation of industrial R\&D over the last 25 years. Taking Mowery's work (Industrial and Corporate Change, 2009, 18(1), 1-50) on the US as a starting point, we reconsider the different aspects of structural change he examined, discuss their impact and the overall logic underlying them. We then examine Europe to discover to what extent these structural changes have occurred in recent years. While a certain structural evolution is perceptible, it is not on the same scale as that analysed for the US. Finally, we consider the extent to which the new structures are more or less 'efficient' than previous ones. We conclude with the implications for R\&D and innovation policy implications.
\end{abstract}

$\mathrm{T}$ HIS PAPER ANALYSES THE structural changes that have characterised the organisation of industrial R\&D over the last 25 years. Taking Mowery's work (2009) concerning the case of the US as a starting point, we reconsider the different aspects of structural change examined by him, discuss their impact and attempt to bring to light the overall logic of these transformations. According to Mowery, the fundamental reorganisation of R\&D, as developed during the last 30 years in the US, is particularly characterised by more complex forms of industrial structures (vertical disintegration) in which a new sector occupies an important place (firms specialising in R\&D and innovation 'services') and by the larger role played by market transactions in the coordination of innovative activities. The intensive use of intellectual property (IP) and licence agreements is the logical completion of this development, something that is occurring especially in the new high-tech industries.

\footnotetext{
D Foray (corresponding author) and S Lhuillery are at the Institut de Management de la Technologie et Entrepreneuriat, Collége du Management de la Technologie, Ecole Polytechnique Fédérale de Lausanne, Station 5, CH-1015, Lausanne, Switzerland; Emails: dominique.foray@epfl.ch and stephane. lhuillery@epfl.ch; Tel: +41 2169 30035; Fax: +41 216930020.

The authors are grateful for the scholarly advice and suggestions from D C Mowery and to K Smith and P MoncadaPaternò-Castello for their encouragement and patience.
}

We then examine the case of Europe to discover to what extent these same structural changes have occurred. While a certain structural evolution is perceptible, it is not on the same scale as that analysed for the US. We try to understand why this is so by identifying the effects of industrial specialisation in particular. Europe's difficulty in achieving a leading position in the new high-tech industries is closely linked with the weakness of structural change, although the direction of causality is obviously difficult to determine.

Finally, we ask ourselves to what extent the new structures are more or less 'efficient' than previous ones. In this respect we note that these new structures, in which the technology market is a powerful incentive mechanism facilitating the coordination of activities, still have significant inefficiencies, which in actual fact stem from the functioning of this market. We conclude with R\&D and innovation policy implications, which in our opinion logically derive from this analysis, in general and for Europe in particular.

\section{Structural changes in industrial R\&D in the US: 1980-2005}

The structural changes that industrial R\&D has undergone over the last 25 years are considerable. We draw heavily on Mowery's work to identify the main aspects of these changes. We then try to identify some coherence, an economic logic, in these changes. 
Professor Dominique Foray holds the chair of economics and management of innovation (CEMI) in the Management of Technology and Entrepreneurship Institute (MTEI) at the Ecole Polytechnique Fédérale de Lausanne. From 2005 to 2009 Professor Foray was vice-chairman of the expert group 'Knowledge for Growth'; a group of prominent economists created to advise Commisioner J Potocnik (European Commission, Directorate-General for Research). His research interests include: the economics and management of technology, knowledge and innovation at both the micro- and macro-levels. This broad field covers the economics of science and technology, international comparisons of institutions, and systems of innovation within the context of the new economy. In particular, he has focused on IP and competition policies, information technology and the new economy, capital market and entrepreneurship, and national systems of innovation. He is recognised as one of the leading academic experts in the economics of innovation and knowledge and economic policy implications of the new knowledge-based economy.

Dr Stéphane Lhuillery is a researcher at CEMI in the MTEI at the Ecole Polytechnique Fédérale de Lausanne. His research interests include: R\&D partnerships and networks, technology diffusion, user innovation and science and technology (S\&T) policy. He is the co-author of ' $R \& D$ cooperation and failures in innovation projects: Empirical evidence from French CIS data', published in Research Policy (2009), and 'How to play the 'Names Game': Patent retrieval comparing different heuristics' also published in Research Policy (2009), and is the author of 'Voluntary technological disclosure as an efficient knowledge management device: an empirical study' Economics of Innovation and New Technologies (2006).

\section{Toward a new landscape}

In a carefully documented paper, Mowery (2009) demonstrates that by the early 21st century, the landscape of US industrial R\&D has totally changed in relation to its structure 30 years earlier. ${ }^{1}$ The following aspects deserve some consideration.

The science-based entrepreneurial dynamic The 'third industrial revolution' (Mowery, 1995) driven by information and communications technologies (ICT) and biotechnology is characterised by the entry of new firms into emerging markets. These firms are small, R\&D-intensive and service oriented.

A first insight into this evolution is provided by the entrepreneurial phenomenon which brought about important structural change, altering the roles of large and small firms as R\&D performers: the proportion of industry-funded R\&D investment carried out by very large firms (over 25,000 employees) dropped from 60\% in 1984 to less than 32\% by 2007 (Wolfe, 2009). Firms with less than 500 employees (small- and medium-sized enterprises (SMEs)) increased their share of R\&D performance from 6\% in 1984 to $19 \%$ in 2007 (Wolfe, 2009). Moreover, the figures for micro-firms are certainly downward biased by the difficulties involved in measuring R\&D activities carried out by early-stage companies.

The entry of new firms is especially associated with increasing specialisation in inventive activity. These new firms are specialised in narrow segments of the industry value chain, segments that are often placed in the upstream phase of the innovation process. As a result, industry structures become somewhat unusual and much more complicated as they accommodate 'industries' intermediate between public research and large companies. For instance, by the mid-1990s, several thousand biotechnology ventures had been launched and several had survived and reached a sufficient size to constitute an important force in the industry (Cockburn, 2003). Existing vertical relationships were disrupted and reformed. Patenting and licensing played a critical role in the establishment of these new vertically disintegrated structures (see below).

This entrepreneurial activity fosters the growth of high added-value services and the related increase of R\&D investments in these sectors: nonmanufacturing R\&D investment increased from 5\% of total company R\&D investment in 1990 to nearly $30 \%$ by 2007 . Even if the data may reflect a reclassification of a few large US firms from the manufacturing to the non-manufacturing category during the period (Shackelford, 2007), they show that the growth of non-manufacturing $R \& D$ reflects the expansion of market-oriented knowledge-intensive services (see Table 1) and the importance of R\&D expenditures in information activities or professional, scientific and technical services. ${ }^{2}$

A more collaborative $R \& D$ The increase in interfirm R\&D and technology-based alliances occurred

Table 1. Global gross revenue (in US\$ trillions at 2000 prices) of market-oriented knowledge-intensive and other service industries in the US, 1986-2005

\begin{tabular}{|c|c|c|c|c|c|}
\hline Industry & 1986 & 1995 & 2000 & 2005 & $\begin{array}{l}\text { Average annual } \\
\text { growth (\%) }\end{array}$ \\
\hline All service industries & 20.24 & 27.52 & 33.06 & 38.49 & 3.3 \\
\hline Market-oriented knowledge-intensive services & 4.54 & 6.86 & 9.44 & 11.52 & 4.8 \\
\hline Service industries not classified as market-oriented knowledge-intensive & 15.71 & 20.66 & 23.62 & 26.67 & 2.7 \\
\hline Market-oriented knowledge-intensive share of all services (\%) & 22.4 & 24.9 & 28.6 & 29.9 & $\mathrm{n} / \mathrm{a}$ \\
\hline
\end{tabular}

Notes: $\quad$ n/a not applicable

Knowledge-intensive services classified by the OECD and consisting of business, financial, communications, education, and health services. Market-oriented knowledge-intensive services exclude education and health services. Gross revenue includes purchases of domestic and imported materials and inputs

Source: Global Insight, Inc., World Industry Service database, special tabulations in NSF (2008) 
partly due to the entry of vertically specialised firms. The R\&D survey data underlines the surge of extramural $R \& D$ expenditures by firms during the period 1993-2003 (National Science Foundation (NSF), 2006), whereas the data provided by the Cooperative Agreements and Technology Indicators (CATIMERIT) show a clear trend of increasing alliances between firms (NSF, 2006) at the national but also the international level.

The number of $R \& D$ alliances between US and non-US firms rose sharply during the period 19802003, showing that the R\&D activity of US firms is becoming more globalised; however, more than half of these collaborations remain intra-US. Although information concerning rates of dissolution and also the average size of these alliances is lacking, these figures remain striking. They also indicate that this phenomenon particularly characterised the $R \& D$ intensive sectors, especially biotechnology and ICT. At the beginning of the 1980s, US alliances were primarily entered into by ICT firms. ICT alliances stagnated after the internet bubble burst whereas those in biotechnology were still growing (Table 2). Another interesting feature is the significant growth in the share of contract-based alliances (e.g. licensing, shared resources and competencies) versus equity-based alliances (e.g. partial acquisitions or joint ventures) (see NSF, 2006).

To conclude the presentation of this first round of evidence, empirical observation emphasises the development of an industry structure populated by firms that specialise in somewhat narrow activities and who contract with other firms that specialise in different activities within the industry. In such a new structure, innovation relies heavily on a complex web of contracts linking a variety of actors at various stages.

The growing role of patents in industry and university These structural changes (notably the vertical disintegration of industries and the emergence and surge of a science-based entrepreneurial dynamic) are closely associated with the increasing importance of patenting and licensing.
Many events, involving key institutional changes (Jaffe, 2000) as well as certain critical court decisions, have created the so-called pro-patent era in the US, which is characterised by a considerable rise in patent applications since 1984. This growth has placed a tremendous strain on patent offices. Since grant rates remain stable, the annual number of patents granted has increased dramatically. New subject matters, the increasing complexity of patents (as measured by the number of claims), strategic use, a growing number of patents dealing with scientific information and tools as well as the increasing likelihood of litigation are other aspects of this evolution. Such a sharp increase is largely attributable to filings from business firms and institutional inventors residing in the US and is concentrated in a few sectors (Hall, 2004). This pro-patent environment has probably strengthened IP markets, leading to an increase in licensing transactions and facilitating the financing and entry of new firms who possess a small number of valuable patents.

Finally, the growth in university patenting/ licensing has attracted a lot of attention from academics and policy-makers and is usually associated with the Bayh-Dole Act (1980) that allowed performers of publicly funded research to file for patents and grant exclusive licenses. Universities increased their share of patenting from less than $2 \%$ in the 1980 s to $4.8 \%$ by 1999 , although this share had already begun to grow before the Bayh-Dole Act. The new law therefore provides only a partial explanation and was in a sense more an endogenous response to the patenting and licensing increase that had already begun rather than an exogenous cause. Some other factors, such as the more general propatent environment as well as the dramatic increase in the federal budget for biomedical research, played a central role. Since 1999, however, the share of college and university patenting as a percentage of US non-governmental patents decreased to $4.2 \%$ in 2005, showing that academics have not succeeded in following the rhythm of industry. Since 2005, the number of academic patents granted has decreased despite an increase in invention disclosures and

Table 2. Technology alliances at triadic level, by technological fields, in period 1980-2003

\begin{tabular}{|c|c|c|c|c|c|c|c|c|c|}
\hline \multirow{2}{*}{$\begin{array}{l}\text { Field } \\
\text { Period }\end{array}$} & \multicolumn{3}{|c|}{ Biotech } & \multicolumn{3}{|c|}{ ICT } & \multicolumn{3}{|c|}{ Other } \\
\hline & 1980-1987 & 1988-1995 & 1996-2003 & 1980-1987 & 1988-1995 & 1996-2003 & 1980-1987 & 1988-1995 & 1996-2003 \\
\hline Intra-Europe & $17 \%$ & $16 \%$ & $16 \%$ & $21 \%$ & $9 \%$ & $8 \%$ & $23 \%$ & $21 \%$ & $18 \%$ \\
\hline USA-Europe & $24 \%$ & $37 \%$ & $34 \%$ & $23 \%$ & $23 \%$ & $25 \%$ & $22 \%$ & $30 \%$ & $33 \%$ \\
\hline Intra-USA & $33 \%$ & $37 \%$ & $42 \%$ & $28 \%$ & $50 \%$ & $47 \%$ & $16 \%$ & $29 \%$ & $34 \%$ \\
\hline USA-Japan & $15 \%$ & $6 \%$ & $6 \%$ & $16 \%$ & $13 \%$ & $11 \%$ & $15 \%$ & $11 \%$ & $6 \%$ \\
\hline Intra-Japan & $8 \%$ & $1 \%$ & $1 \%$ & $6 \%$ & $2 \%$ & $5 \%$ & $14 \%$ & $4 \%$ & $3 \%$ \\
\hline Europe-Japan & $3 \%$ & $3 \%$ & $2 \%$ & $7 \%$ & $4 \%$ & $4 \%$ & $10 \%$ & $6 \%$ & $5 \%$ \\
\hline Other zones & $6 \%$ & $10 \%$ & $14 \%$ & $7 \%$ & $10 \%$ & $20 \%$ & $13 \%$ & $21 \%$ & $17 \%$ \\
\hline Total & 522 & 722 & 1715 & 867 & 1580 & 1393 & 699 & 1035 & 866 \\
\hline
\end{tabular}

Source: Cooperative Agreements and Technology Indicators (CATI-MERIT). Data from the Science and Engineering Indicators (NSF 2006). Calculations made by the authors. Note that some alliances are classified in several categories simultaneously. 'Other' is the sum of aerospace/defence, car and chemical industries. Possible double counting is not taken into account 
royalty payments (see NSF, 2008: Appendix Tables 5-40 and 5-42).

\section{Is there any underlying economic logic?}

Is there any economic sense behind these rather different structural changes? Is there a puzzle with these various aspects forming the different pieces that, once assembled, will provide a meaningful picture? To recapitulate, we have observed that the growth of small (new) firms and the declining importance of large firms as R\&D performers are both associated in a complex way with increasing vertical specialisation, involving the creation of highly focused segments in the upstream phases of the innovation process. The growth of contract-based alliances and the considerable increase in patenting and licensing (in general and from academia) also constitute important parts of this picture. All of these trends occurred mostly in a few new high-tech industries.

Since the various dimensions documented above are critically interdependent they may at times exhibit complementarities. The pro-patent environment is strengthening IP markets, facilitating the signalling, financing and entry of new firms and leading to an increase in licensing and other knowledge dissemination activities (Lhuillery, 2006). Such an IP market also supports the development of vertical specialisation since firms are able to specialise and license their results to other firms. Partly because of the entry of vertically specialised firms, extramural R\&D expenditures as well as R\&D alliances have grown and strong IP may facilitate greater reliance on contractual rather than equity-based governance. ${ }^{3}$ Finally, universities contribute to both the market for technologies and the entry of new science-based entrepreneurs.

Chesbrough (2003), among others, argues that the high-tech firms must nowadays collaborate more with external direct or indirect partners in order to achieve better innovative performances. However, this 'openness' strategy is not new and was already applied by firms in the decades from 1880 to the 1920s according to Mowery and Rosenberg (1989) and was successfully used as a strategy by some companies in the 1980s (Barabaschi, 1992). A further step is to understand the mechanisms underpinning this evolution. Mowery (2009) rightly argues that the profound economic sense which best captures the essence of the different structural changes documented might be found in the 'greater reliance on market relationships for the governance of the $R \& D$ and innovation process', mirroring a decrease in transaction costs (Arora et al., 2001; Mowery, 2009).

\section{Europe: structural changes are under way, but at a more modest pace}

The familiar picture about R\&D in Europe is that EU firms still remain significantly less R\&D-intensive than their US counterparts. Current explanations of this feature involve two arguments: first, the EU is not specialised into high-tech sectors and is more specialised into the less R\&D-intensive services sectors. Secondly, the high-tech industry and high-tech services are more R\&D intensive in the US (European Commission, 2008). Despite important efforts to gather and harmonise data sets (EUKLEMS, 2009), R\&D data are still missing at the sectoral level (Arundel et al., 2007), hampering a detailed comparison between the EU and the US. The caveat particularly concerns the growing business services and especially knowledge-intensive business services (KIBS). In the following paragraphs, we will first highlight some differences between the EU and the US based on available patent and R\&D data and offer an interpretation of these trends. We then advocate that the structural evolution of the EU system is also slower due to the influence of policies: the US system is more prone to support the emergence of new activities.

\section{Europe's path towards structural changes in industrial $R \& D$}

We first contend that the structural changes occur in Europe at a more modest pace (see also Gambardella et al., 2007). Despite the lack of relevant data, we articulate three statistical features. First, we show that Europe has not profoundly changed its knowledge base (i.e. its specialisation structure) and exhibits a much lower development of new high-tech activities. A second feature is that Europe failed to create as much as knowledge in business services as the US did. Finally, we suggest that Europe has maintained a quite traditional model of transferring academic knowledge and information whereas the new R\&D organisation in the US involves a new model of technology transfer between universities and industries (where the new high-tech service firms play the central role of knowledge brokers).

First, the variation in the ability of countries to transform their specialisation and develop new activities is an important element of the explanation for the differences in the rate and magnitude of structural changes between the US and Europe since most structural changes (increasing role of small firms as R\&D performers, vertical disintegration of 
industries, growth of alliances, R\&D internationalisation, growth of patenting and licensing) have mainly occurred in a set of new industries and services. The very fact that Europe has indeed failed to develop these new activities is clearly demonstrated in Figure 1, based on triadic patents.

Figure 1 shows how countries changed (or maintained) their technological specialisations during the two last decades of the 20th century. The trend toward the north and north-east quadrants shows a higher weight of new industries (ICT and biomedical fields). Hence, Canada, Finland, France, Sweden, the UK, and US were less and less specialised in the vehicle or organic chemistry industries and more and more in computer technologies and ICT over time. The length of the segments shows how profound these changes were. Figure 1 underlines that Canada, France, Sweden and the UK moved their specialisation over time but not sufficiently to build a new one. On the contrary, the US and Finland, as well as Denmark, Germany or Japan are clearly more specialised and maintain or reinforce their specialisation over time. Finland is the only one of the 15 member states of the EU before May 2004 (EU-15) that succeeded in embarking on the ICT revolution to a

\section{The US is the only large country that has succeeded in building a clear specialisation in the new fields over the last 20 years}

sufficient degree to transform the change into a clear specialisation. Correspondingly, Denmark is the only EU-15 country clearly specialised in agro-biopharma technologies. Thus, the US is the only large country that has succeeded in building a clear specialisation in the new fields over the last 20 years, whereas Germany and Japan remain in the same technology segments. Despite some changes and some specialised countries, the members of the EU15 as a whole remain specialised in the automotive industry, organic chemistry, mechanical engineering and textiles over the period reflecting the traditional specialisations of countries like Germany, Austria, Italy and Switzerland. Figure 1 confirms the leadership

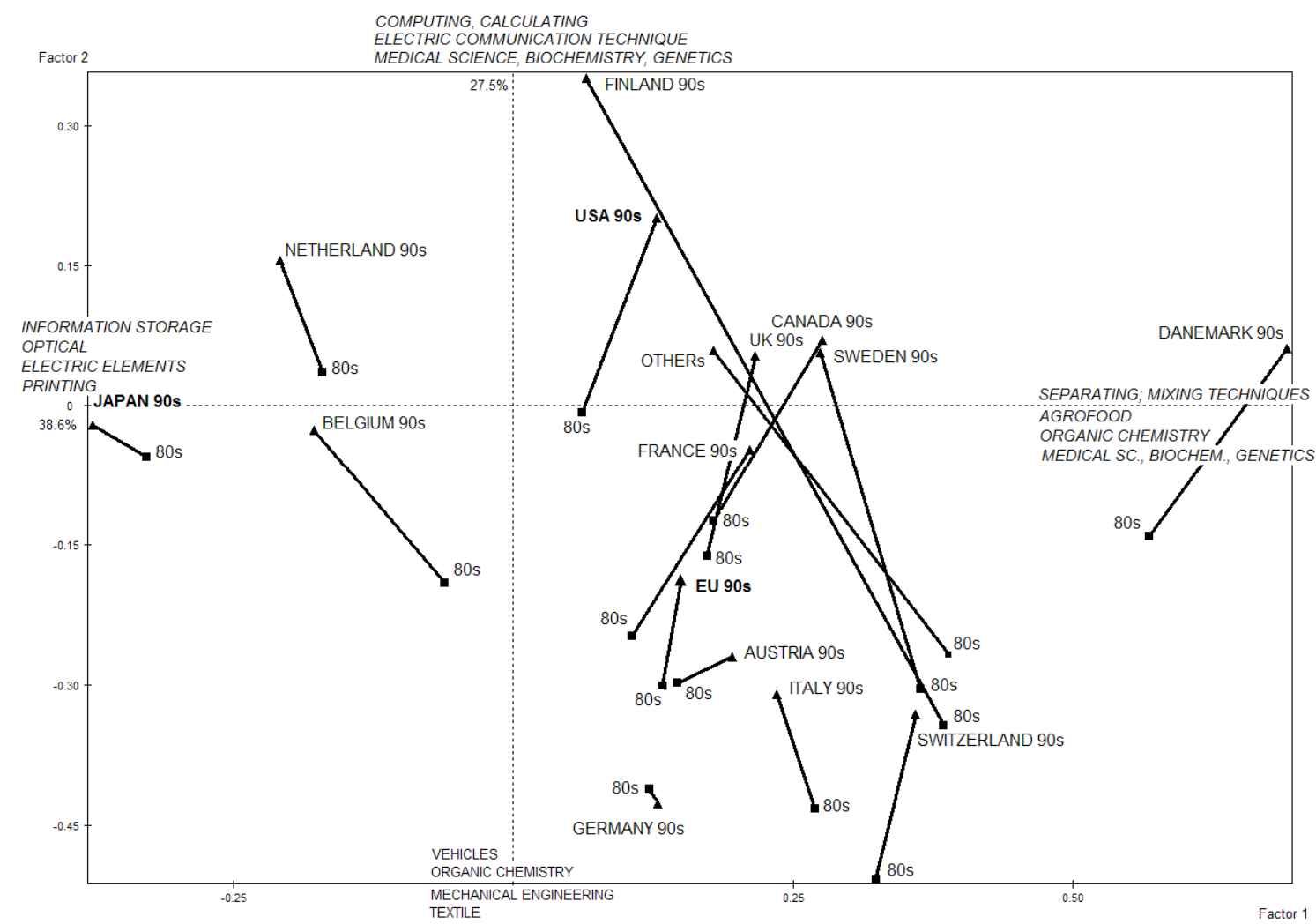

Figure 1. Evolving structure of national triadic patent portfolios, 1991-2000 versus 1981-1990

Notes: $\quad \Delta 1990$ s $=1991-2000$, - 1980s $=1981-1990$

EU is EU-15, Others are other OECD countries

First two axes explain $66 \%$ of variance in our component factor analysis. Axes are computed on 1990 s period using the different countries. The EU90s value is not taken into account in the computation of the axes as well as the 1980s plots: they are projected afterwards to give an idea of the structural evolution over the two periods. The arrows thus depict the changing profiles in knowledge production in a country according to two axes. The horizontal axis opposes for example a specialisation in microelectronics to a specialisation in the agro-food technologies; the vertical axis, opposes ICT to vehicle industries. The more central the country is, the less specialised it is

Source: Data taken from OECD triadic patents. Available at $<$ http://stats.oecd.org/Index.aspx?DatasetCode=PATS IPC>, last accessed 16 June 2010 
of the US in the third industrial revolution. It also confirms that Europe, with few exceptions, is lagging behind in these technologies and remains stuck in its 'old' knowledge specialisations.

The evolution displayed in Figure 1 tells only one part of the story: the ability of countries to transform their specialisations is the key to explaining the importance and magnitude of structural changes in R\&D. However, Figure 1 does not capture the structural changes themselves: what is happening within sectors with regard to corporate R\&D? And the second part of the story, already discussed in the introduction to this paper, also makes a distinction between the US and Europe, which is the evolution of countries towards a high-value service economy where R\&D firms and other specialised innovation services are competing and trading with universities and the industrial $\mathrm{R} \& \mathrm{D}$ laboratories of large companies to produce and develop technological knowledge.

Secondly, the EU did not succeed in creating these new segments in the upstream phases of the innovation process in the ICT and biotechnology industries. Figure 2 shows that the transformation of industry in this respect was much greater and faster in the US than in the EU. The US transformation involved a significant increase in specialised R\&D producers classified as belonging to the service industries. ${ }^{4}$ While the EU is keeping pace with the US with regard to industrial $R \& D$, it has failed to create an equivalent entrepreneurial R\&D and high-tech fringe in $R \& D$ and innovation services that are important complementary assets for competitive innovation (Passi, 1999).

The European difficulties or delay at creating these complementary activities (Passi, 1999;
Castaldi, 2009) have a direct impact on growth: whereas the new high-tech services or more precisely the so-called KIBS are boosting productivity in the US, they are possibly a hampering factor for productivity growth in Europe (Castaldi, 2009).

Thirdly, we compare the share of higher education funded by industry in Europe and the United States. Figure 3 actually shows some similarities between the US and EU: like their US counterparts, EU firms have been significantly involved since the end of the 1980s in university funding. However, the evolution of US academic funding since 1999 shows a considerable difference between the two regions. Whereas in the US, firms have decreased their financial support, there is no such tendency in the case of the EU where universities represent a growing part of extramural business R\&D expenditures. One possible interpretation (among several, not mutually exclusive) is that in the US, new R\&D performers (start-ups, services) entered massively, as a result of the structural changes already documented, and captured a growing share of industrial and even federal funding. For example, the US National Institutes of Health (NIH), which have benefited from the main increases in federal $R \& D$ funding over the last ten years, spent more than twice the 2000 amounts in 2007 (US\$2.0 billion) with industrial firms. The share of firms in external contracts grew from $4 \%$ to $10 \%$ over the period (NIH, 2008).

Figure 3 shows that the evolution was not the same for Europe. This might be interpreted in terms of the continuing dominance of the 'old structure' with not so many new actors trying to share the cake.

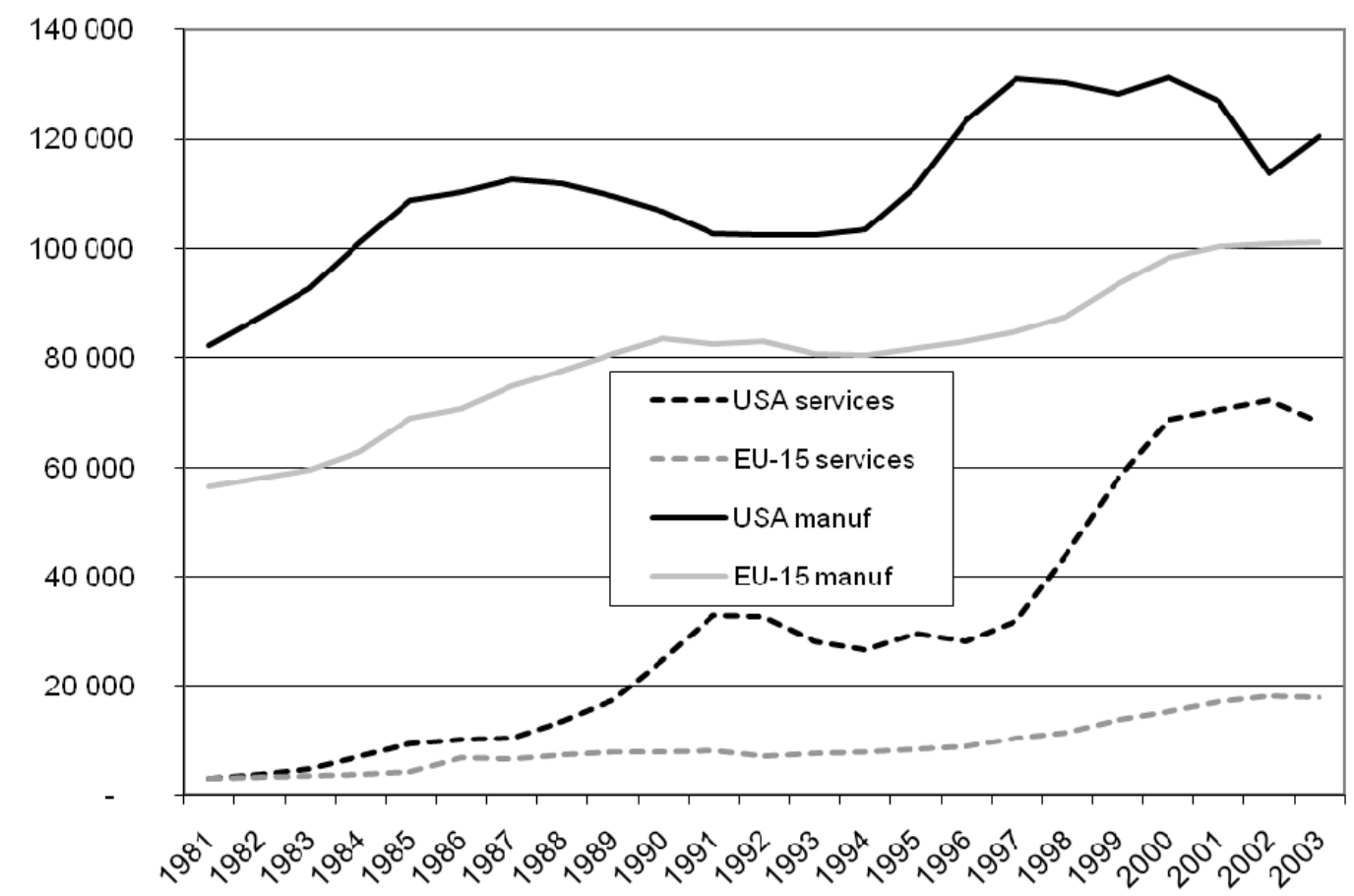

Figure 2. Business R\&D levels by sectors, in US\$ million (at 2000 prices)

Source: Data taken from OECD (2007) 


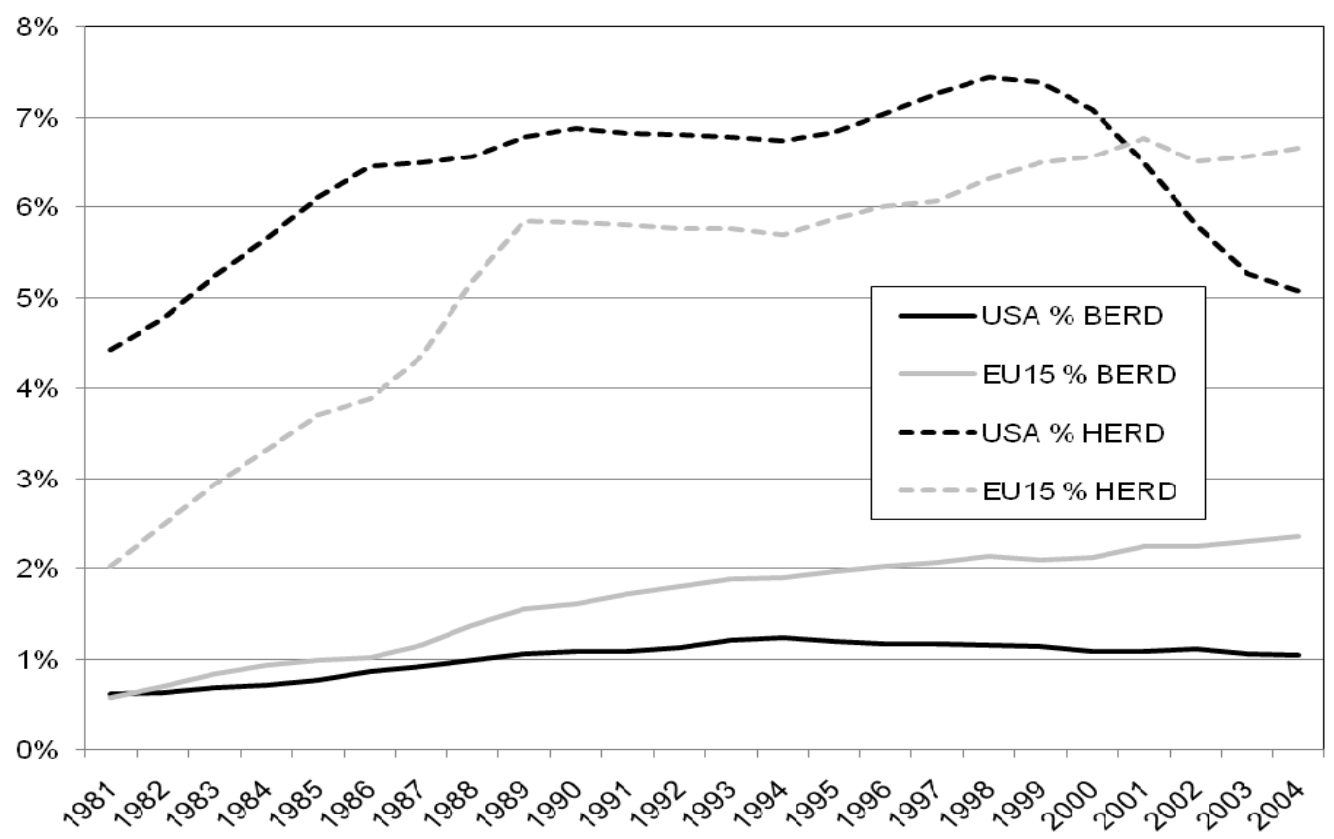

Figure 3. Higher education R\&D financed by industry as \% of BERD and HERD, 1981-2004

Notes: $\quad$ BERD $=$ business expenditure on R\&D

HERD = higher education expenditure on R\&D

Source: Data taken from OECD (2007)

\section{The influence of policies}

One factor that certainly explains the difference between the importance and magnitude of structural changes in corporate R\&D in the US and the EU concerns the centrality of governmental R\&D policy in the US as a driver of these structural changes. We distinguish four policy areas that have clearly impacted the whole process: government S\&T policies, market regulations, intellectual property rights (IPR) rules, and financial regulations.

First, government R\&D spending must be considered (Dinges et al., 2007). In this respect, some aspects of the structural changes in the US are clearly related to the federal funding shift from defencerelated to biomedical fields (Rosenberg, 2009). Figure 4 shows trends in funding of the two main government budget appropriations or outlays for R\&D (GBAORD), which are health and environment (H\&E) and defence R\&D (defence) spending. It suggests that any fluctuation in US federal spending which involves reallocation across fields, is likely to have a huge impact on R\&D activities (entry and exit, reorganisation) simply because the amounts spent are huge. So new priorities in biomedical research or ICT, as translated into federal R\&D budget reallocation, are likely to drive the evolution mentioned above - the growth of new types of R\&D firms specialised in narrow upstream segments of the biomedical or ICT industries. While the gap between the US and EU narrowed a little during the 1990s, the remaining difference (increasing again since 2003) represents a very large amount (roughly US\$4 billion in current purchasing power parity). The share of H\&E in civil GBOARD increased from $35 \%$ in the US to $59 \%$ over the last 20 years whereas the increase at the European level was only from $13 \%$ to $19 \%$ over the period (see Figure 5).

The early reallocation of the European Commission funding over the period is remarkable but remains too small to significantly influence the transformation of the European system. The evolution depicted in Figure 4 combined with the evolution of the GBOARD structure in Figure 5 suggests the remarkable ability of the US system to shift resources and research capabilities to more productive use whenever possible; such an ability being a critical determinant of success.

Secondly, economic and regulatory policies also play a role. On antitrust policy, successive US administrations reduced the power of antitrust restrictions on R\&D collaboration. US antitrust policy has also played a strong role in facilitating the vertical disintegration of new industries and the competitive entry of new firms. As shown in many recent reports, despite a similar permissive regulation on R\&D cooperation, competition policy in Europe has historically emphasised competition between incumbent firms, but paid little attention to entry (Sapir et al., 2004; Aghion, 2006). For example, the EU or European national administrations did not pay much attention to the regulation of the market for $\mathrm{R} \& \mathrm{D}$ services and accepted the competitive entry of academic bodies without considering the possible negative impact of it on the innovation system.

Thirdly, another important focal point regarding policy involves changes in and adaptation of the patent and other IPR systems so that new fields were opened to patentability, a more effective legal system was set up and new guests (universities) were invited to take part in the banquet (Jaffe, 2000; Scherer, 2007). Nororiously, the adjustment of the 


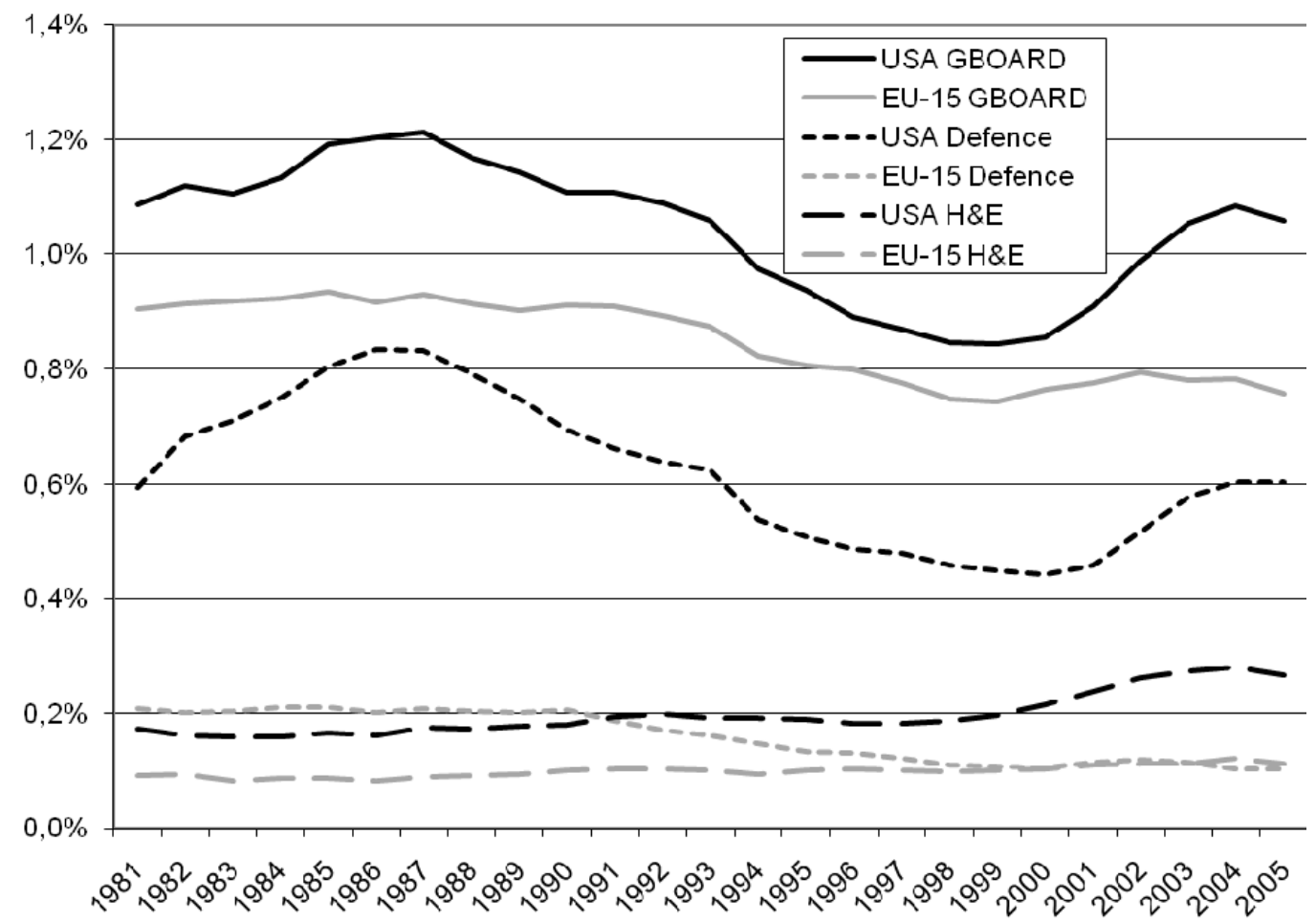

Figure 4. GBAORD, as \% of GDP, by objectives, 1981-2005

Source: Data taken from OECD (2007)

European patent system to the third industrial revolution has been much slower than in the US where pragmatic attitudes adopted by the patent office and legal institutions have always been the rule in order to accommodate innovators in new fields, at the expense of relaxing evaluation standards for patentability and hampering their rigorous implementation. A number of new subject matters are still under discussion in Europe (living organisms, software) while others are simply not considered for patentability (business methods). The average cost of patent application and examination remains much higher in Europe than in the US. As a possible consequence, European firms and particularly the small high-tech companies experience difficulties in using the European patent system to appropriate their innovative efforts and the small firms do not use the US system where the costs of IPR enforcement are dissuasive. $^{5}$

Fourthly, changes in the rules for financing new firms leading to customised financial solutions for start-ups and fast movers were an important policy step toward the new industrial structure (Reynolds and Curtin, 2008). First, the new rules allow pension funds to invest in venture capital (VC) firms and take stakes in risky companies listed on the Nasdaq (new pension fund regulations 1974-1979). Secondly, these rules involved the transformation of the Nasdaq into a stock market specialised in innovative firms (1980s), particularly since after the 1980s nonprofitable firms could be listed. These firms were allowed to include a whole range of 'intangibles' in their financial statements, notably their patents and other IPRs. In this way a new 'exit option' was opened up for VC firms and an abundant supply of
VC was generated. While US biotechnology firms were flooded with money in the 1980s, European companies could barely find financing since they were not listed and there was thus no easy 'exit' for venture capitalists. The EU regulation has recently been adapted: restrictions for listing on the London Stock Exchange ceased in 1995, and in 1996 the same thing occurred in France (Nouveau Marché). The lagging development of ICT firms and even biotechnology firms in Europe is partly due to EU delays (15 years) in adapting financial rules. As proof, and despite the internet bubble, the rate of formation of new companies in Europe has surged and VC investment in European firms has grown rapidly in Europe especially in the UK and France (European Commission, 2006), the first countries to be deregulated.

\section{Doubts concerning the efficiency of the new system}

The final section of this paper is devoted to a discussion of the efficiency of the new R\&D structures that have emerged following 20 years of change. The structural changes described above form a system of interdependent forces that reinforce each other and clearly push the structure away from the previous organisation, at least in a few new industries.

\section{The pros and cons}

In the 'old days' the two major players in inventive activities were the public research sector that produced and put basic knowledge and certain kinds of 


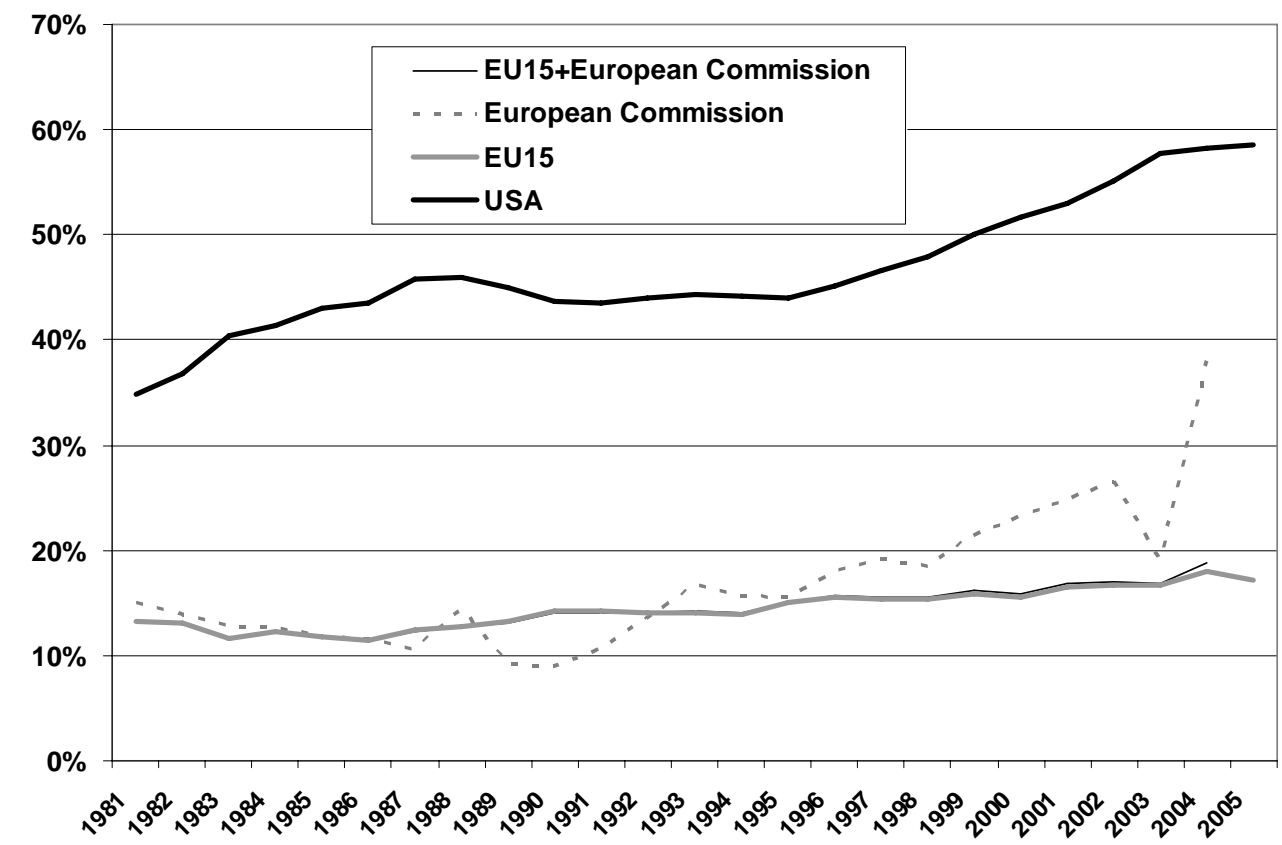

Figure 5. Share of civil H\&E in civil GBAORD, 1981-2005

Source: Data taken from OECD (2007)

technologies (instrumentation for example) into the public domain, and the large firms that used this knowledge to develop products. As a matter of fact, the large integrated firm was quite effective in solving numerous management and control problems usually associated with R\&D investments (long-term risk, imperfect appropriability, complex monitoring issues, sunk costs, shared costs and vertically complementary outcomes) (Cockburn, 2003). In the context of large, vertically integrated firms, $R \& D$ productivity was driven by economies of scale and scope and the ability to capture internally and externally generated spillovers. This ability was facilitated by a moderate level of patenting activities, with firms allowing diffusion of their own knowledge in return for low-cost absorption of others' knowledge, and a large public research domain. In this context, the public domain containing a stock of freely accessible information was a key factor that greatly influenced the efficiency of innovation processes. That shared collection of basic knowledge provided the building blocks for new inventions.

The structural changes documented above resulted in a shift from this system toward a new one: a much more complicated structure that is vertically disintegrated. There are reasons to believe that vertical specialisation can bring efficiency gains (Cockburn, 2003):

- Specialisation: large integrated firms minimise some costs but can raise others (internal bureaucracy, rigidity, conservatism); new firms are faster and more cost-effective at developing new technologies. They exhibit advantages in terms of specialisation, focus and high-powered incentives.

- Market driven resource allocation: large incumbent firms can slow down technical progress; they have incentives to shelve or abandon some innovation in order to avoid cannibalizing their existing products.

- Intensified competition: supporting a market for R\&D services and patents on upstream technologies can speed up progress in science; large integrated firms have incentives to develop basic technologies in secret; this is socially costly because knowledge spillovers and social returns are lower than if basic technologies are disclosed through patent applications.

Baumol (2002) has described and analysed these efficiency gains, which stem from the increasing role played by market relationships in inventive activities. He devotes a great deal of attention to the role of markets in technology dissemination. Starting with the right idea that dissemination is no minor matter for the efficiency of the economy's growth process, he shows how markets for technology may play an effective role in that dissemination process under simple conditions. While economists usually see a conflict between (incentives to) innovation and dissemination (uncompensated and/or too rapid dissemination discourages firms from undertaking innovative activities that cost money and effort since they expect to be unable to capture a substantial fraction of the social return on their investments), Baumol claims that an efficient market for technology will considerably alleviate this problem.

Since dissemination through market transactions provides a means of obtaining a 'sufficient reward' from innovation, if the price is right, then it follows that it will pay the firm to permit others to use its technology. This will happen if the firm that wants to buy is a more efficient user than the owner of the technology. ${ }^{6}$ In such circumstances, the market will 


\section{Even for inventions that the owner wishes to license, the probability of this occurring remains very low (around 5\%)}

succeed in partially reconciling innovation and dissemination.

However, Baumol's world is an ideal construction far removed from reality. It can even be said that it is rare to find another market with as many market failures. A recent survey addressed to IP officers working in large US corporations (Cockburn, 2007) illustrates the point very clearly:

- Transactions in technological knowledge are complex and costly.

- A large fraction of the total IP inventory appears not to be licensable.

- More than one-third of a firm's total IP inventory is rated as being unlikely to be licensed even though the firm is willing to transact.

As a result, even for inventions that the owner wishes to license, the probability of this occurring remains very low (around 5\%). The obstacles to licensing impose two major types of costs:

- Deals not done (underuse of IP).

- Incorrect prices: price signals in competitive markets are widely believed to induce behaviour by participants that results in socially optimal resource allocation. When prices are 'wrong' there is no such guarantee and quite poor outcomes may result.

Of course, sectoral differences matter. In a few sectors, these markets work relatively well and these are the sectors where IPR boundaries are clearly defined (Bessen and Meurrer, 2008). But there are many sectors where this is not the case, and surprisingly many high-tech sectors (i.e. where structural changes are significantly altering the organisation of the innovation process) are characterised by inefficient markets for technologies, particularly in cases where vertical disintegration gives rise to new specialised segments which are positioned very upstream (Cockburn, 2002, 2003, and 2005 for the cases of business methods, biotechnology, bio-informatics; Lemley, 2005 for nanotechnologies).

In conclusion, we argue that markets for technologies are generally much more inefficient than most other markets. The fact that the structural changes described above lead to the centrality of this mechanism for the governance of R\&D and the innovation process is a matter of concern.
The structural changes are leading to a system that is still confronted by problems with inefficiency and policy responses are important for anyone who takes what has been described in this paper seriously. We need to distinguish between two categories of policy responses.

The first policy response concerns Europe (Foray and Van Ark, 2008). In Europe, experts and policymakers have not understood the magnitude and centrality of the structural changes in corporate $\mathrm{R} \& \mathrm{D}$ occurring in the US during the last 25 years and at a more modest pace in Europe and that we have summarised, following Mowery, with the notion of a greater reliance on market relationships for the governance of $R \& D$ and innovative activities. Clearly, we have observed a co-evolution of the corporate $R \& D$ structures and the institutional framework in the US, but not in Europe. There is therefore a need for institutional adjustments so that our institutions better match the new structures and organisation of innovative activities in the emerging fields.

We need the proper institutions for an effective development of this economy of vertical specialisation, start-ups, fast movers and new industries. Institutions in continental Europe are rather weak at promoting economic dynamism, in terms of entrepreneurship and the ability of financial markets to steer finance towards worthy innovations. In fact, they tend to be good at suppressing this dynamism. Therefore the relatively poor economic performance of Europe results in both the underdevelopment of capitalist institutions like VC and equity finance, and the overdevelopment of corporatist institutions which suppress innovation and competition. These corporatist institutions impose penalties, impediments, prohibitions and mandates generally intended to damp down 'creative destruction'. There is, therefore, a case for continental Europe to create a new balance between capitalist institutions and corporatist institutions. Facilitating entry into business, creating tailored financing solutions for emerging firms (Phillipon and Véron, 2008) as well as radically transforming the governance and mode of operation of the university system are policy actions of particular relevance for Europe that are amply discussed and supported in many reports (Aghion, 2006; Aghion et al, 2007; Philippon and Véron, 2008; van Pottelsberghe de la Potterie, 2008).

The second category of policy response to these structural changes is more general in nature (in the sense of relevant for any advanced economy), and this concerns fixing markets for technology. Indeed we have just discussed their relative inefficiencies, whereas the structural changes described above have placed them in an eminent position as coordinators of R\&D and innovative activities. Such a policy direction involves (Cockburn, 2007): 
- mitigating information problems by increasing transparency through better public reporting of IP transactions, providing more extensive and regular data on trade in technology, reforming financial accounting standards which govern the valuation of intangibles;

- promoting standardised contracts and market norms;

- developing market infrastructures (low-cost dispute resolution mechanisms, insurance against certain risks); and

- of course, reforming the patent system to increase patent quality.

Resolving market failures should be an important objective in the case of markets for technology if we take the argument about the centrality of market transactions in the governance of innovation and $\mathrm{R} \& \mathrm{D}$ processes seriously.

\section{Notes}

1. Most of the data used to document these changes in the US were obtained from National Science Foundation reports.

2. These correspond to the 73-74 NACE codes (Eurostat, 2002).

3. Few statistics are available on licensing transactions. How ever, the surge of cross-border royalties since the 1990s suggests their growing importance (Guellec, 2008).

4. The EUKLEMS database also underlines that the value added in business services grows faster in the US. Certain reclassifications regularly made at country level (see Shackelford, 2007) should not modify the conclusion. It can, however, also be argued that in Europe a larger share of R\&D services are provided by non-profit organisations and are thus not included in the usual KIBS or R\&D service statistics based on for-profit business surveys.

5. Citing a 2003 survey, Hoti and McAleer (2006) say that the average costs of patent and trademark litigation in the US are, respectively, US $\$ 2$ million and US $\$ 600,000$.

6. The superior efficiency of the buyer means that it can earn more from its use than the technology owner can. So the buyer can still earn a profit even if it pays a licence fee somewhat greater than the amount the owner would be able to earn by using the technology itself. Under such conditions, the seller is better off licensing the technology, and the buyer is better off buying and using it.

\section{References}

Aghion, P 2006. A primer on innovation and growth. Bruegel Policy Brief No. 2. Brussels: Brussels European and Global Economic Laboratory.

Aghion, P M Dewatripont, C Hoxby, A Mas-Colell and A Sapir 2007. Why reform Europe's Universities? Bruegel Policy Brief No. 4. Brussels: Brussels European and Global Economic Laboratory.

Arora, A, A Fosfuri and A Gambardella 2001. Markets for Technology - The Economics of Innovation and Corporate Strategy. Cambridge, MA: MIT Press.

Arundel, A, M Kanerva, A van Cruysen and $\mathrm{H}$ Hollanders 2007. Innovation Statistics for the European Service Sector. Maastricht, the Netherlands: UNU-MERIT.

Barabaschi, S 1992. Managing the growth of technical information. In Technology and the Wealth of Nations, R Landau, D C Mowery and N Rosenberg (eds.), pp 407-434. Palo Alto, CA: Stanford University Press.

Baumol, W J 2002. The Free-Market Innovation Machine: Analyzing the Growth Miracle of Capitalism. Princeton, NJ: Princeton University Press.
Bessen, J and M J Meurer 2008. Patent Failure: How Judges, Bureaucrats, and Lawyers Put Innovators at Risk. Princeton, NJ: Princeton University Press.

Castaldi, C 2009. The relative weight of manufacturing and services in Europe: An innovation perspective. Technological Forecasting and Social Change, 76(6), 709-722.

Chesbrough, H W 2003. Open Innovation: The New Imperative for Creating and Profiting from Technology. Cambridge, MA: Harvard Business School Publishing.

Cockburn, I 2002. Business method patents: what are they good for? Conference on Frontiers of Ownership in Digital Economy, Paris: IFRI.

Cockburn, I 2003. O brave new industry, that has such patents in it! Reflections on the economic consequences of patenting DNA. In Perspective on Properties of the Human Genome Project, F S Kieff (ed.), pp 385-398. St Louis, MO: Elsevier Academic Press.

Cockburn, I 2005. State Street Meets the Human Genome Project: Intellectual Property and Bioinformatics. In Intellectual Property Rights in Frontier Industries: Biotechnology and Software, R Hahn (ed.), pp 109-130. Washington, DC: AEIBrookings Press.

Cockburn, I 2007. Is the market for technology working? Obstacles to licensing inventions, and ways to reduce them. Monte Verita Conference on the Economics of Technology Policy, held 17-22 June 2007, Ascona, Switzerland.

Dinges, M, M Berger, R Frietsch and A Kaloudis 2007. Monitoring sector specialisation of public and private funded business research and development. Science and Public Policy, 34(6), 431-443.

EUKLEMS, 2009. Data available at <http://www.euklems.net/>, last accessed 16 June 2010.

European Commission 2006. Developing European Private Equity. Report of the Alternative Investment Expert Group, Internal Market and Services DG. Brussels: European Commission.

European Commission 2008. A more research-intensive and integrated European research area. Science, Technology and Competitiveness Key Figures Report 2008/2009. Brussels: European Commission.

Eurostat, 2002. Statistical Classification of Economic Activities in the European Community, Rev. 1.1 (2002) (NACE Rev. 1.1). Available at <http://ec.europa.eu/eurostat/ramon/ nomenclatures/index.cfm?TargetUrl=LST_CLS_DLD\&StrNom $=$ NACE $11>$, last accessed 16 June $20 \overline{10}$.

Foray, D and B Van Ark 2008. Overview on Knowledge for Growth: European issues and policy challenges. In Knowledge for Growth, EUR 23725. Brussels: Directorate-General for Research, European Commission.

Gambardella, A, P Giuri and A Luzzi 2007. The market for patents in Europe. Research Policy, 36(8), 1163-1183.

Guellec, D 2008. Who licenses out and why? Lessons from a survey of European and Japanese firms. 3rd Annual Conference of the EPIP Association, held 3-4 October 2008, Bern, Switzerland.

Hoti, S and M McAleer 2006. How does country risk affect innovation? An application to foreign patents registered in the USA. Journal of Economic Surveys, 20(4), 691-714.

Hall, B 2004. Exploring the patent explosion. Journal of Technology Transfer, 30(1/2), 35-48.

Jaffe, A 2000. The US patent system in transition: policy innovation and the innovation process. Research Policy, 29(4/5), 531-557.

Lemley, M 2005. Patenting nanotechnology. Stanford Law School, Working Paper No. 304. Palo Alto, CA: Stanford Law School.

Lhuillery, S 2006. Voluntary technological disclosure as an efficient knowledge management device: an empirical study. Economics of Innovation and New Technology, 15(4/5), 465-491.

Mowery, D C 1995. The boundaries of the U.S. firm in R\&D. In Coordination and Information: Historical Perspectives on the Organization of Enterprise, N Lamoreaux and D Raff (eds.), pp 147-182. Chicago, IL: NBER/University of Chicago Press.

Mowery, D C 2009. Plus ça change: industrial R\&D in the third industrial revolution. Industrial and Corporate Change, 18(1), $1-50$.

Mowery, D C and N Rosenberg 1989. The US research system before 1945. In Technology and the Pursuit of Economic Growth, D C Mowery and N Rosenberg (eds.), pp 59-97. New York: Cambridge University Press. 
NIH 2008. Mechanism Detail, Total NIH, FY 1983-FY2007. Available at <http://officeofbudget.od.nih.gov/Ul/SpendingHistory. htm>, last accessed 16 June 2010.

NSF 2006. Science and Engineering Indicators, Chapter 4. The National Science Board. Arlington, VA: National Science Foundation.

NSF 2008. Science and Engineering Indicators 2008, (two volumes). Arlington, VA: National Science Foundation.

OECD 2007. Main Science and Technology Indicators (MSTI), 2007/2 edn. Paris: OECD.

Paasi, M 1999. Weak competitiveness of EU R\&D intensive industries - Result of insufficient investment in complementary intangible assets? Background paper for The competitiveness of European industry: 1999 report, Working Paper No. 5. Brussels: Directorate General for Enterprise, European Commission.

Phillipon, T and N Véron 2008. Financing Europe's fast movers. Bruegel Policy Brief No. 1. Brussels: Brussels European and Global Economic Laboratory.

Reynolds, P D and R T Curtin 2008. Business creation in the United States: Panel Study of Entrepreneurial Dynamics II Initial Assessment. Foundations and Trends in Entrepreneurship,
4(3), 155-307.

Rosenberg, $\mathrm{N}$ 2009. Some critical episodes in the progress of medical innovation: An Anglo-American perspective. Research Policy, 38(2), 234-242.

Sapir, A, P Aghion, G Bertola, M Hellwig, J Pisani-Ferry, D Rosati and $\mathrm{J}$ Vinals 2004. An Agenda for a Growing Europe. Oxford, UK: Oxford University Press.

Scherer, F M 2007. The Political Economy of Patent Policy Reform in the United States. KSG Working Paper No. RWP07042. Available at <http://ssrn.com/abstract $=963136>$, last accessed 16 June 2010.

Shackelford, B 2007. Revised Industry Classification Better Reflects Structure of Business R\&D in the United States. InfoBrief NSF-07-313, Science Resources Statistics. Arlington, VA: National Science Foundation.

Van Pottelsberghe de la Potterie, B 2008. Europe's R\&D: missing the wrong targets? Bruegel Policy Brief No. 3. Brussels: Brussels European and Global Economic Laboratory.

Wolfe, R M 2009. U.S. Business R\&D Expenditures Increase in 2007; Small Companies Performed 19\% of Nation's Business $R \& D$. InfoBrief NSF-09-316, Science Resources Statistics. Arlington, VA: National Science Foundation. 